\title{
Agricultural Support Policies and Public Budgeting in Turkey
}

\author{
Sibel Tan, Sabri Sami Tan, Bengü Everest \\ Çanakkale Onsekiz Mart University, Çanakkale, Turkey \\ Mehmet Hasdemir \\ Ministry of Food, Agriculture and Livestock, Ankara, Turkey
}

\begin{abstract}
Agriculture is a leading strategic sector in Turkey as it is in entire world. Despite this strategic significance, risks, and uncertainties, the dependence on natural conditions turns agriculture into a disadvantaged sector. Just because of these disadvantages, agriculture is protected by various support policies throughout the world. Agricultural policies of Turkey have initiated with institutionalization policies of the Republican period and progressed through product supports, input supports, and low-interest credit implementations of the planned period. These policies experienced serious reforms at the beginning of 2000s. Within the scope of Agricultural supports and Reforms Implementation Project (ARIP), agricultural supports tried to be gathered under a single roof and Direct Income Support (DIS) implementations started. The DIS implementations lasted for eight years and terminated in 2008. The aim of this study is to examine agricultural supports in Turkey and their shares in the public budget. As material, macroeconomic data are used in this study. The data consist of transfers from the ministry of food, agriculture, and livestock to agriculture and budget numbers. The results of the study reveal that current agricultural policy tools are implemented as area-based supports, subsidiary payments, rural development, and agricultural insurance supports. The budget allocated to agriculture and the share of agricultural supports in Gross Domestic Product (GDP) of Turkey does not exhibit much change in years. Considering the policies and supports provided in developed countries and especially in European Union (EU) countries, it recommend for Turkey that the share of agricultural supports in total budget should be increased to levels in those countries.
\end{abstract}

Keywords: agriculture, agricultural policy, policy instruments, budget, Turkey

\section{Introduction}

As it is in entire world, agriculture is both a national and an international strategic industry in Turkey, especially with regard to nourishment of public. Considering the share in national income, employment, and foreign trade, agriculture has perpetually sustained the significance among economic sectors of Turkey. According to Turkish Statistics Institute (TUIK, 2015a; 2015b), by the year of 2014, agriculture had 8.8\% share

Sibel Tan, assoc. professor, Department of Agricultural Economics, Faculty of Agriculture, Çanakkale Onsekiz Mart University, Çanakkale, Turkey.

Sabri Sami Tan, asst. professor, Department of Public Finance, Çanakkale Onsekiz Mart University, Çanakkale, Turkey.

Bengü Everest, research assistant, Ph.D., Department of Agricultural Economics, Faculty of Agriculture, Çanakkale Onsekiz Mart University, Çanakkale, Turkey.

Mehmet Hasdemir, agricultural engineer, Ph.D., Ministry of Food, Agriculture and Livestock, Ankara, Turkey.

Correspondence concerning this article should be addressed to Sibel Tan, Department of Agricultural Economics, Faculty of Agriculture, Çanakkale Onsekiz Mart University, Çanakkale 17100, Turkey. 
in Gross Domestic Product (GDP), 21.10\% share in total employment, 3.82\% share in export, and 3.54\% share in import of the country.

Despite such significance in country economy, agriculture is a disadvantaged sector with various risks and uncertainties because of dependence on natural conditions. Just because of these disadvantaged characteristics, agriculture is the primary sector protected by support policies throughout the world, especially in developed countries. As it was again in entire world, agricultural policies of Turkey also aim to improve income and welfare level of producers, to provide price stability, rural development, and foreign exchange savings (Tan, 2011).

Agriculture is the primary means of living in rural sections throughout the world. Therefore, it is evident that agricultural supports are effective in reducing poverty in rural parts of the country. However, such supports are not alone sufficient in explaining farmer welfare and rural poverty. There are several natural, economic, social, cultural, and even political factors affecting agricultural and rural welfare levels (Demirdöğen, Ören, \& Alemdar, 2012).

In Turkey, various agricultural policy implementations and tools have been used since the proclamation of the republic, especially since the beginning of planned periods in 1963. With the beginning of planned period, agricultural support policies have been implemented in five-year plans, regulated in annual programs and maintained with agricultural support purchases for years. However, support purchases became secondary issues in economy policy implementations after 1980. The number of supported products was rapidly decreased from 29 to 22 in 1980, to 13 in 1985, and to 10 in 1990. The number was again raised in 1991 and 1992, respectively to 24 and 26. With economic stability measures on 5 April 1994, price-guaranteed support purchases were limited with cereals, tobacco, and sugar beet (Abay, Sayan, Miran, \& Bayaner, 2001).

The greatest renovation in Turkish agricultural support policies was implemented at the beginning of 2000s with Agricultural Reforms Implementation Project (ARIP) including Direct Income Support (DIS). Direct Income Support was proposed as an alternative to already implemented support policies. DIS implementations resulted in termination of some other supports and direct supports reached to a share of $78 \%$ in entire supports in 2002. However, in 2006-2010 Agricultural Law and Strategy Document, it was decided that $78 \%$ share allocated for direct supports should be gradually reduced to $45 \%$ (Karaman \& Yavuz, 2012). DIS implementations were ultimately terminated in 2008.

Current agricultural supports implemented in Turkey can be classified under plant production supports, animal production supports, structural improvement supports, rural development, and environmental supports. Various biological control supports, fuel, fertilizer and soil analyses supports, agricultural consultancy, and farm accounting data network registration supports are the supports provided to improve agricultural infrastructure. The support program for rural development investments (KKYDP) and environment-oriented agricultural land preservation (CATAK) project are also among the policies implemented by the ministry within the scope of rural development and environment. In addition, 50\% state supported agricultural insurance (TARSIM) implementations are provided as a policy tool for risk management and stable producer income.

These agricultural policies and consequent structural and technological developments have brought about significant changes in Turkish agriculture during the last decade. Despite decreasing total agricultural lands and sowing areas, increases were observed in production levels of wheat, barley, sun flower, corn, and cotton. Similarly, production levels are also increasing in animal production because of culture and breeding races. Despite decreasing ratio of agriculture in GDP and employment, agricultural growth rates were positive in all 
years except for 2007 global climate change crisis. With the implemented rural development policies, agricultural and dependent industries exhibited significant improvements. Producers had taken significant steps in guaranteeing their incomes through 50\% state-supported agricultural insurance implementations ( $\mathrm{S}$. Tan, Atak, Ümran, \& S. S. Tan, 2015).

In this study, changes experienced in supports provided to producers within the scope of agricultural policies in Turkey were investigated. Also, the annual shares of these supports in country budget were assessed.

\section{Share of Agricultural Supports in Budget of Turkey}

Budgets are basic tools of public finance of a state to perform the tasks assigned. With budgets, states indicate the type and amount of expenditures and put forth the level of success of a state in meeting the social needs (Buhur, 2012). Therefore, as it was in legislation, security, justice, education, and health sectors, budget sizes and shares are also significant issues in agricultural sector.

The share of agriculture in county budget of Turkey during the last 10 years is provided in Table 1 . While central administration budget size of agriculture was 3.084 million TL (Turkish Lira) in 2004, the value increased about three folds and reached to 9.470 million TL in 2014. The share of central administration budget size of agriculture in GDP did not exhibit many changes in years and observed as between $0.5-0.6 \%$. The share of central budget allocated to agriculture in total budget was $2.0 \%$ in 2004 . The value increased to $2.7 \%$ in 2006 and observed as $2.6 \%$ in 2007. Later on, the ratio decreased again and stayed between $2.0-2.2 \%$. While the share of agricultural supports in interest-free management expenses was $3.2 \%$ in 2004 , the value increased to $3.6 \%$ in 2006 and decreased to $2.5 \%$ in 2014. As an important indicator, considering the increases in annual central administration budgets in agriculture, the increase was $20.2 \%$ in 2004 compared to previous year and the value was $17.0 \%$ in 2006 compared to previous year. The ratio increased by $4.6 \%$ in 2007 but decreased by $22.6 \%$ in 2008. The basic reason for this decrease was global climate crises and consequent global economic crises experienced in 2007. In subsequent years, the increase ratios were observed as $19.7 \%$ in $2010,15.0 \%$ in 2012, and $9.0 \%$ in 2014 .

Table 1

Shares of Agricultural Support Payments in Budget

\begin{tabular}{|c|c|c|c|c|c|c|c|}
\hline & 2004 & 2006 & 2007 & 2008 & 2010 & 2012 & 2014 \\
\hline $\begin{array}{l}\text { Central administration budget sizes in agriculture } \\
\text { (million TL) }\end{array}$ & 3.084 & 4.747 & 5.555 & 5.809 & 6.961 & 8.684 & 9.470 \\
\hline $\begin{array}{l}\text { Shares of central administration budget sizes of } \\
\text { agriculture in GDP }(\%)\end{array}$ & 0.6 & 0.6 & 0.7 & 0.6 & 0.5 & 0.5 & 0.6 \\
\hline $\begin{array}{l}\text { Shares of central administration budget sizes of } \\
\text { agriculture in total budget }(\%)\end{array}$ & 2.0 & 2.7 & 2.7 & 2.6 & 2.0 & 2.1 & 2.2 \\
\hline $\begin{array}{l}\text { Shares of central administration expenses of } \\
\text { agriculture in interest-free management expenses }(\%)\end{array}$ & 3.2 & 3.6 & 3.6 & 3.3 & 2.4 & 2.4 & 2.5 \\
\hline $\begin{array}{l}\text { Year-on-year changes in central administration budgets } \\
\text { in agriculture }(\%)\end{array}$ & 20.2 & 17.0 & 4.6 & -22.6 & 19.7 & 15.0 & 9.0 \\
\hline
\end{tabular}

Source: T. C. Maliye Bakanliği. 2015 Yili Bütçe Gerekçesi.

Although more than $20 \%$ of country population earn their lives from agriculture, the shares provided to agriculture and agricultural supports during the last 10 years were quite lower than the budget items allocated to other sectors. Considering the increasing ratios provided to agriculture in developed European Union countries, such low ratios in Turkey should be pointed out as an important issue. 


\section{Distribution of Agricultural Supports Based on Support Types and Years}

From the beginning of planned period to the beginning of 2000s, agricultural supports in Turkey were implemented as product-based supports, input supports, and low-interest agricultural credits. From the year 2000, serious reforms were implemented with Agricultural Reforms Implementation Project (ARIP) and since then area-based supports and rural development policies have been brought to agenda. Today, such supports are being implemented in plant production as fuel, fertilizer, soil analyses, biologic control, agricultural consultancy, and farm accounting data system registration supports. Supports are also provided in animal production activities as to improve yields, preserve gene sources, and have alternative income sources. Also, $50 \%$ grant supports are provided to agricultural projects to provide the agriculture-industry integration. Land consolidation and agricultural insurance implementations are also performed to strengthen agricultural infrastructure and to improve producer incomes.

The payments made to agriculture based on types of support are provided in Table 2. During the last 10 years, while the support provided to agriculture was 3.049 million TL in 2004, the value increased three folds and reached to 9.056 million TL in 2014. Considering the distribution of these supports to area of support, it was observed that area-based direct income supports decreased in time and ultimately terminated in 2008. In addition, compensation payments, subsides, and livestock supports increased in time. Rural development supports increased from the year of 2006 as a part of Agricultural Reforms Implementation Project. The supports allocated for agricultural insurances started to be implemented with the inaction of TARSIM law in 2006. For once only, drought support was provided in 2007 with global climate crises and freeze support was provided in 2010.

Table 2

Distribution of Agricultural Supports Based on Types and Years

\begin{tabular}{lccrrrr}
\hline Type of support (million TL) & 2004 & 2006 & 2008 & 2010 & 2012 & 2014 \\
\hline Area-based supports and DIS & 2.444 & 2.661 & 1.953 & 1.859 & 2.167 & 2.406 \\
Subsidies & 350 & 1.290 & 1.647 & 2.071 & 2.379 & 2.691 \\
Livestock supports & 250 & 679 & 1.330 & 1.193 & 2.216 & 2.589 \\
Supports related to Agricultural Reforms Project & 1 & 2 & 34 & 0 & 0 & 0 \\
Agricultural insurance & 0 & 2 & 55 & 81 & 263 & 357 \\
Compensation payments & 4 & 73 & 80 & 77 & 99 & 123 \\
Other agricultural supports & 0 & 37 & 93 & 124 & 194 & 274 \\
Rural development supports & 0 & 0 & 109 & 284 & 196 & 313 \\
Rural Development Program (IPARD) supports & 0 & 0 & 0 & 0 & 39 & 303 \\
Drought support & 0 & 0 & 549 & 0 & 0 & 0 \\
Freeze disaster & 0 & 0 & 0 & 128 & 0 & 0 \\
GENERAL TOTAL & 3.049 & 4.744 & 5.851 & 5.881 & 7.635 & 9.056 \\
\hline
\end{tabular}

Source: T. C. Gida Tarim ve Hayvancilik Bakanliği (2014). Tarim Reformu Genel Müdürlügü Verileri (2004-2015).

Proportional distribution of agricultural supports is provided in Table 3. Among the total supports, area-based direct income supports had the greatest ratio in 2004 with $80.1 \%$. The ratio of this implementation decreased in time and finally terminated in 2008. The ratio of area-based fuel, fertilizer and soil analysis supports in total supports was observed as $26.6 \%$ in 2014 . While the ratio of subsides was $11.5 \%$ in 2004 , the value reached to $28.6 \%$ in 2014 . Among the agricultural policies implemented and agricultural supports provided 
during the last 10 years, the supports provided for livestock or animal production were the most remarkable ones. While the ratio of livestock supports was $8.2 \%$ in 2004 , the value reached to $29.7 \%$ in 2014 . Agricultural insurance is a 50\% state-supported implementation and started to be implemented from 2006 and the ratio in total today is $3.9 \%$. The ratio of other supports provided within the scope of the projects implemented by the Ministry of Food Agriculture and Livestock was 3.5\% and the ratio of IPARD rural development supports was $3.3 \%$ in 2014. Finally, the ratio of compensation payments in total supports was around $4.1 \%$.

Table 3

Proportional Distribution of Agricultural Supports Based on Types and Years

\begin{tabular}{|c|c|c|c|c|c|c|}
\hline Type of support (\%) & 2004 & 2006 & 2008 & 2010 & 2012 & 2014 \\
\hline Area-based supports and DIS & 80.1 & 56.1 & 33.4 & 31.6 & 28.4 & 26.6 \\
\hline Subsidies & 11.5 & 27.2 & 28.1 & 35.2 & 31.2 & 29.7 \\
\hline Livestock supports & 8.2 & 14.3 & 22.7 & 20.3 & 29.0 & 28.6 \\
\hline Supports related to Agricultural Reforms Project & 0.0 & 0.0 & 0.6 & 0.0 & 0.0 & 0.0 \\
\hline Agricultural insurance & & 0.0 & 0.9 & 1.4 & 3.4 & 3.9 \\
\hline Compensation payments & 0.1 & 1.5 & 1.4 & 1.3 & 1.3 & 1.4 \\
\hline Other agricultural supports & & 0.8 & 1.6 & 2.1 & 2.5 & 3.0 \\
\hline Rural development supports & & 0.0 & 1.9 & 4.8 & 2.6 & 3.5 \\
\hline Rural Development Program (IPARD) supports & & 0.0 & 0.0 & 0.0 & 0.5 & 3.3 \\
\hline Drought support & & 0.0 & 9.4 & 0.0 & 0.0 & 0.0 \\
\hline Freeze disaster & & 0.0 & 0.0 & 2.2 & 0.0 & 0.0 \\
\hline GENERAL TOTAL & 100.0 & 100.0 & 100.0 & 100.0 & 100.0 & 100.0 \\
\hline
\end{tabular}

Source: T. C. Gida Tarim ve Hayvancilik Bakanliği (2014). Tarim Reformu Genel Müdürlüğü Verileri (2004-2015).

\section{Conclusion and Recommendations}

In this study, the shares of agricultural supports in country budget of Turkey and distribution and variation of these supports based on types and years during the last 10 years were investigated. The share of central budget size of agricultural sector in GDP did not exhibit much variation in years and varied between $0.5-0.6 \%$. While the share of the budget size allocated to agricultural sector in total budget was $2.0 \%$ in 2004 , the value increased to $2.7 \%$ in 2006 , and realized as $2.6 \%$ in 2007 . Then the ratio decreased in subsequent years and commonly varied between $2.0-2.2 \%$.

Considering the proportional distribution of agricultural supports, it was observed that $80 \%$ of supports were provided to producers as direct income support in 2004. The ratios of current supports were $29.7 \%$ in subsidies, $28.6 \%$ in livestock supports, $26.6 \%$ in area-based supports, $3.9 \%$ in agricultural insurances, $3.5 \%$ in rural development supports, $3.3 \%$ in IPARD supports, and $1.4 \%$ in compensation payments. Considering the variations in these supports during the last 10 years, while an increase was observed in subsides, livestock supports, rural development, and agricultural insurance supports, a decrease was seen in area-based supports because of termination of DIS.

Current findings revealed that the share of agriculture in total budget was quite low compared to other sectors and such a share did not change much despite the continuous changes in agricultural and support policies. Considering the distribution of the supports based on types, it was observed that the increase in livestock supports and subsidiary payments made especially to supply-deficit products were considered as positive outcomes of implemented support policies. 
Moving from these outcomes, it is recommended initially that the budget allocated to agriculture in Turkey should be increased to levels in developed countries. Moreover, Basin-based Support Models should be developed and put into action to utilize regional production potential. Projects should also be prepared to benefit from grants to improve agriculture-dependent industries, project preparation, and implementation potentials of producer organizations should be improved. Increasing producer consciousness levels on agricultural policies, reducing bureaucratic barriers in use of agricultural supports, and improving farmer training will definitely improve the efficiency of implemented agricultural policies of the country.

\section{References}

Abay, C., Sayan, S., Miran, B., \& Bayaner, A. (2001). Türkiye'deki tarimsal destek harcamalarının enflasyonist, etkilerinin ekonometrik analizi. Ankara: TEAE Yayinlari.

Buhur, S. (2012). Tarimsal destekleme ödemelerinin bütçe içerisindeki payinin analizi, Vergi Sorunlari Dergisi. Retrieved from http://www.vergisorunlari.com.tr/makale/tarimsal-destekleme-odemelerinin-butce-icerisindeki-payinin-analizi/2814

Demirdöğen, A., Ören, M. N., \& Alemdar, T. (2012). Türkiye'de tarim politikalari kapsaminda saglanan destekler ve kirsal yoksulluk. Ulusal Tarim Ekonomisi Kongresi, 10, 85-94.

Karaman, C., \& Yavuz, F. (2014). Dünyadaki eğilimler işiğinda türkiye tarimsal destekleme politikalarinin değerlendirilmesi. Ulusal Tarım Ekonomisi Kongres Kitabi, 11, 929-937.

Tan, S. (2011). Türkiye'de uygulanan tarim politikalari kapsaminda çanakkale'nin mevcut durumu. Çanakkale Tarımı Sempozyumu Kitabi, 37-44.

Tan, S., Atak, Ş., Ümran, Ş., \& Tan, S. S. (2015). The evaluation of the changes in the agricultural sector with common economic indicators in Turkey during the last decade. Mediterranean Journal of Social Sciences, 6(2), 588-595.

T. C. Gida Tarim ve Hayvancilik Bakanliği. (2014). Tarim Reformu Genel Müdürlüğü Verileri (2004-2015).

T. C. Maliye Bakanliği. (2015). 2015 Yili bütçe gerekçesi. Retrieved from https://pbk.tbmm.gov.tr/dokumanlar/2015_merkezi_yonetim_butce_tasarisi.pdf

TUIK. (2015a). Istihdam, işsizlik ve ücret istatistikleri. Retrieved from: http://www.tuik.gov.tr/UstMenu.do?metod=temelist

TUIK. (2015b). Diş ticaret istatistikleri. Retrieved from http://www.tuik.gov.tr/PreTablo.do?alt_id=1046 